\title{
The wealth decumulation behavior of the retired elderly in Italy: the importance of bequest motives and precautionary saving
}

\author{
Luigi Ventura $^{1} \cdot$ Charles Yuji Horioka ${ }^{2,3,4,5}$
}

Received: 2 October 2018 / Accepted: 1 April 2020 / Published online: 30 April 2020

(c) The Author(s) 2020, corrected publication 2021

\begin{abstract}
In this paper, we analyze the wealth accumulation and saving behavior of the retired elderly in Italy using micro data from the "Survey of Italian Households' Income and Wealth," a panel survey of households conducted every 2 years by the Bank of Italy. We find that, on average, the retired elderly in Italy are decumulating their wealth (dissaving) but that their wealth decumulation rates are much slower than expected. Moreover, we also find that more than $40 \%$ of the retired elderly in Italy are continuing to accumulate wealth and that more than $80 \%$ are doing positive amounts of saving. Thus, the Wealth Decumulation Puzzle (the tendency of the retired elderly to decumulate their wealth more slowly than expected) appears to apply in the case of Italy, as it does in most other countries, before as well as after the Global Financial Crisis. Moreover, our regression analysis of the determinants of the wealth accumulation and saving behavior of the retired elderly in Italy suggests that the lower than expected wealth decumulation rates and dissaving of the retired elderly in Italy is due largely to intergenerational transfers (bequests and inter vivos transfers) and saving for precautionary purposes, especially the former.
\end{abstract}

Keywords Aged - Bequests - Bequest intentions - Bequest motive - Dissaving · Elderly $\cdot$ Estates $\cdot$ Household saving $\cdot$ Italy $\cdot$ Inheritances $\cdot$ Inter vivos transfers $\cdot$ Intergenerational transfers $\cdot$ Life-cycle hypothesis $\cdot$ Life-cycle model $\cdot$ Life-cycle theory $\cdot$ Precautionary saving $\cdot$ Retired elderly $\cdot$ Saving $\cdot$ Wealth $\cdot$ Wealth accumulation $\cdot$ Wealth decumulation $\cdot$ Wealth decumulation puzzle

Jel Classification D12 $\cdot \mathrm{D} 14 \cdot \mathrm{D} 15 \cdot \mathrm{D} 64 \cdot \mathrm{E} 21 \cdot \mathrm{J} 14$

Charles Yuji Horioka

horioka@rieb.kobe-u.ac.jp

1 Department of Economics and Law, Sapienza, University of Rome, Rome, Italy

2 Research Institute for Economics and Business Administration, Kobe University, 2-1, Rokkodai-cho, Nada-ku, Kobe, Hyogo 657-0813, Japan

3 Institute of Social and Economic Research, Osaka University, Ibaraki, Japan

4 Asian Growth Research Institute, Kitakyushu, Japan

5 National Bureau of Economic Research, Cambridge, MA, USA 


\section{Introduction}

The central tenet of the life-cycle model is that people work, earn income, and save (accumulate wealth) when young and retire and dissave (decumulate wealth) when old. However, previous studies for most countries have found that the elderly continue to accumulate wealth (save) or that they decumulate their wealth (dissave) but that their rate of wealth decumulation is slower than predicted by the simple lifecycle model with no lifespan uncertainty and no bequest motives. For example, the country studies in Poterba (1994) show that median saving rates remain positive well beyond retirement in virtually all countries.

At least two explanations have been proposed for this so-called "Wealth Decumulation Puzzle" (see Mirer 1979, for an early exposition of this puzzle). The first explanation is that the retired elderly are continuing to accumulate wealth or are decumulating their wealth (dissaving) more slowly than expected because they are worried about longevity risk (lifespan uncertainty) and the possibility of facing high medical and long-term care expenses in the future and that they are engaging in precautionary saving in response to these worries. The second explanation, which of course is not mutually exclusive with the first, is that the retired elderly are continuing to accumulate wealth or are decumulating their wealth (dissaving) more slowly than expected because they are saving in order to leave bequests and other intergenerational transfers to their children.

In this paper, we analyze the wealth accumulation and saving behavior of the retired elderly in Italy using micro data from the 2000-2002 and 2012-2014 waves of the "Survey of Italian Households' Income and Wealth (hereafter SHIW)," a panel survey of households conducted every two years by the Bank of Italy. We are particularly interested in shedding light on whether or not the "Wealth Decumulation Puzzle" applies in the case of Italy, and if so, whether it is due to the presence of bequest motives and/or to the presence of precautionary saving.

This paper makes a number of original contributions to the existing literature. First, it is one of the first papers to examine whether the "Wealth Decumulation Puzzle" (the tendency of the retired elderly to decumulate their wealth more slowly than expected) applies in the case of Italy. Second, it is one of the first papers to shed light on the relative importance of bequest motives and precautionary saving as determinants of the wealth accumulation and saving behavior of the retired elderly in Italy. Third, it makes direct use of data on saving motives. Fourth, it is careful to construct a measure of the change in wealth that includes only out-of-pocket saving and excludes capital gains and losses on real estate and other components of wealth. Fifth, it takes account of the endogeneity of bequest intentions and the intended bequest to wealth ratio by instrumenting for these variables. Fifth, it analyzes data before as well after the Global Financial Crisis to see whether the behavior of households changed after the Global Financial Crisis.

This paper is closely related to several strands in the literature. Most obviously, it is related to the many studies that have been conducted in the United States and other countries that attempt to shed light on the relative importance of bequest motives and precautionary saving as explanations for the failure of the retired elderly to decumulate their wealth as quickly as expected. For example, studies for the USA include Bernheim (1987), Hurd (1987), Weil (1994), Poterba et al. (2011), Palumbo (1999), Dynan et al. 
(2002), French et al. (2006), De Nardi et al. (2010), and Ameriks et al. (2020), studies for Europe include Börsch-Supan (1992), Alessie et al. (1995, 1999), and Dobrescu (2015), and studies for Japan include Horioka et al. (1996), Horioka (2010), Usuki et al. (2016), Horioka and Niimi (2017), Murata (2018), and Niimi and Horioka (2019) (see Hurd 1990, De Nardi et al. 2016, and Niimi and Horioka 2019 for more comprehensive literature surveys). Virtually all of these studies find that both bequest motives and precautionary saving are important as explanations for the failure of the retired elderly to decumulate their wealth as quickly as expected.

Looking in particular at previous studies for Italy, Jappelli and Pagano (1997) find that Italian households of all ages save positive amounts even though their saving rates have declined over time for almost all age groups. Similarly, Brugiavini and Padula (2001) find that elderly households in Italy save positive amounts even after controlling for measurement error and cohort effects. Miniaci and Weber (2003) find that Italian households fail to decumulate their financial assets after retirement and that, although their housing wealth appears to decline after the age of 60, this is due largely to cohort effects. Finally, Jappelli and Modigliani (2003) do a detailed analysis of the age-saving profiles and age-wealth profiles of Italian households and find that discretionary wealth (exclusive of pension wealth) declines in old age, at least after the age of 65, but that discretionary saving remains positive throughout the life cycle (at least until age 80) if it is calculated as disposable income minus consumption. These findings, taken as a whole, strongly suggest that the "Wealth Decumulation Puzzle" applies in the case of Italy, as it does in most other countries (see Jappelli et al. 2014 for a more general survey of household saving behavior in Italy).

As for why the "Wealth Decumulation Puzzle" is observed in the case of Italy, Miniaci and Weber (2003) conclude that bequest and gift motives play an important role, and the findings of Guiso and Jappelli (2002), Jappelli and Pistaferri (2005), and Cannari and D'Alessio's (2008) that bequests and other intergenerational transfers are substantial in the case of Italy provide further corroboration for this view.

Turning to evidence on whether or not precautionary saving could be why the Wealth Decumulation Puzzle applies in the case of Italy, Jappelli et al. (2008) find that precautionary saving is not very significant in the case of working-age households in Italy, but this does not necessarily preclude the possibility that longevity risk and the possibility of facing high medical and long-term care expenses in the future motivates elderly households in Italy to engage in substantial precautionary saving. Moreover, Guiso et al.'s (2009) finding that Italians facing more pension wealth risk have a greater demand for targeted retirement saving and insurance suggests that Italians are risk-averse, that they are concerned about their living expenses after retirement, and that they are engaging in precautionary saving for this purpose.

Thus, although there seems to be a consensus that the Wealth Decumulation Puzzle applies in the case of Italy, there does not seem to be a consensus about whether bequest motives or precautionary saving is the more important explanation.

Another strand of literature to which this paper is related is the literature that attempts to assess the relative importance of various saving motives (see, for example, Horioka and Watanabe 1997, Alessie et al. 1999, Horioka et al. 2000, and Schunk 2009). Horioka and Watanabe (1997) and Horioka et al. (2000) find that retirement and precautionary motives are of predominant importance in both Japan and the United States, while Alessie et al. (1999) find that precautionary and bequest 
motives are both important in the Netherlands, and Schunk (2009) finds that the precautionary, retirement, housing, and bequest motives (in roughly that order) are the most important motives for saving in Germany. These findings provide further corroboration that both bequest motives and precautionary saving are important as explanations of the Wealth Decumulation Puzzle.

A final strand of literature to which this paper is related is the literature on bequest motives (see, for example, Hurd 1989, Laitner and Ohlsson 2001, Horioka et al. 2002, Nishiyama 2002, Brown 2006, Altonji and Villanueva 2007, Kopczuk and Lupton 2007, Horioka 2014, and Lockwood 2018; for comprehensive literature surveys, see Arrondel and Masson 2006, and Laferrere and Wolff 2006). This literature analyzes the various motives for which people leave bequests and what impact bequest motives have on people's saving and other behavior.

The analysis in this paper is meaningful not only because it sheds light on the wealth accumulation and saving behavior of the retired elderly (who hold a substantial share of household wealth) and on the applicability of the life-cycle model but also because it has important policy implications. For example, whether and the extent to which the retired elderly decumulate their wealth (dissave) will determine what impact the aging of the population will have on future trends in the aggregate household saving rate, and knowing more about the determinants of the wealth accumulation and saving behavior of the retired elderly will inform us about what policies would be most effective in stimulating the consumption and raising the living standards of the retired elderly.

It is especially interesting to look at the case of Italy because household saving rates have traditionally been very high in Italy, because the share of the elderly in the total population in Italy is the highest in the EU, because the fertility rate is very low in Italy, and because it would be interesting to shed light on the impact of Italy's unique cultural and institutional setting (relatively strong family ties, relatively underdeveloped financial system, high government debt to GDP ratio, well-developed public pension system, absence of a public long-term care insurance system, etc.) on the wealth accumulation and saving behavior of the retired elderly in Italy.

To summarize our main findings, we find that, on average, the retired elderly in Italy are decumulating their wealth (dissaving) but that their wealth decumulation rates are much slower than expected. Moreover, we also find that more than $40 \%$ of the retired elderly in Italy are continuing to accumulate wealth and that more than $80 \%$ are doing positive amounts of saving. Thus, the Wealth Decumulation Puzzle (the tendency of the retired elderly to decumulate their wealth more slowly than expected) appears to apply in the case of Italy, as it does in most other countries, before as well as after the Global Financial Crisis. Moreover, our regression analysis of the determinants of the wealth accumulation and saving behavior of the retired elderly in Italy suggests that respondents with bequest motives and those saving for precautionary purposes show higher wealth accumulation rates and higher amounts of saving than other respondents, which suggests that the lower than expected wealth decumulation rates and dissaving of the retired elderly in Italy is due largely to intergenerational transfers (bequests and inter vivos transfers) and saving for precautionary purposes, especially the former.

The remainder of this paper is organized as follows. In "Theoretical considerations", we discuss theoretical considerations; in "The estimation model", we explain 
the estimation model we use for our regression analysis of the determinants of the wealth accumulation and saving behavior of the retired elderly in Italy; in "Data source and sample selection", we explain the data source and sample selection criteria we use for our analysis; in "Descriptive statistics", we present and discuss some descriptive statistics; in "Estimation results", we present and discuss our estimation results; and "Conclusion" is a concluding section that summarizes our findings and explores the policy implications of our findings.

\section{Theoretical considerations}

In this section, we briefly discuss theoretical considerations. According to the simple life-cycle model, households work and save in preparation for their life after retirement when young and retire and finance their living expenses by decumulating their previously accumulated wealth when old (Modigliani and Brumberg 1954). Moreover, in the absence of bequest motives and precautionary saving arising from longevity risk and future medical and long-term care expenses, retired households should decumulate their wealth so as to precisely exhaust their wealth at the time of death. If the wealth decumulation rate of retired households is slower than predicted by the simple lifecycle model, it is presumably due to bequest motives and/or to precautionary saving arising from longevity risk or future medical and long-term care expenses.

The purpose of this paper is to determine whether the retired elderly in Italy decumulate their wealth (dissave) after they retire as predicted by the simple lifecycle model and whether or not their wealth accumulation and saving behavior is influenced by the presence of bequest motives and precautionary saving.

\section{The estimation model}

In this section, we explain the estimation model we use for our regression analyses of the determinants of the wealth accumulation and saving behavior of the retired elderly in Italy based on data for the 2000-2002 and 2012-2014 waves of the Survey of Households' Income and Wealth.

\subsection{The estimation model for the regressions based on data from the 2000-2002 waves}

\subsubsection{Dependent variables}

We use two dependent variables in our analysis based on data from the 2000-2002 waves of SHIW.

(1) The wealth accumulation (decumulation) rate between 2000 and 2002, calculated as the natural logarithm of the ratio of wealth (net worth) in 2002 to wealth (net worth) in 2000 in 2000 prices (following Spicer et al. 2016). We use a comprehensive measure of wealth that is calculated as the sum of financial and real assets minus liabilities. 
(2) The amount of saving in 2002, calculated as the residual between disposable income and consumption expenditure in 2002. Consumption expenditure is a comprehensive measure of expenditures on both nondurable and durable goods but excludes maintenance payments and other financial contributions to noncohabiting relatives and friends, extraordinary maintenance payments and rent on one's dwelling, and mortgage payments. Expenditures on nondurable goods include expenditures on food products purchased in shops and supermarkets, meals eaten regularly outside the home, and nonfood items, while expenditures on durable goods include expenditures on precious objects, means of transport, furniture, furnishings, household appliances, and sundry articles.

Note that these two measures of wealth accumulation or saving are calculated in totally different and independent ways. The first of them is calculated from the net change in wealth between the 2000 and 2002 waves, while the second of them is calculated using only data from the 2002 wave by subtracting consumption expenditure from household disposable income in that year. Since it is possible to compute wealth accumulation or saving in these two very different ways, we decided to do so as a robustness check.

Turning to the explanatory variables, the ones of most interest to us are the ones relating to bequest motives and precautionary saving.

\subsubsection{Bequest-related variables}

(1) A dummy variable that takes a value of one if the respondent intends to leave a bequest to his or her children or grandchildren and zero otherwise.

(2) The ratio of the amount of the intended bequest that the respondent intends to leave to his or her children or grandchildren to household wealth (net worth).

We would expect both bequest intentions and the ratio of the amount of the intended bequest to wealth (hereafter referred to as the intended bequest to wealth ratio) to have a positive impact on the wealth accumulation rate because households that intend to leave a bequest (or that intend to leave a larger bequest) to their children would be expected to moderate their rate of wealth decumulation so that they have enough wealth left over to leave as a bequest. Thus, if bequest intentions and/or the intended bequest to wealth ratio are found to have a positive and significant impact on households' wealth accumulation rate, we will be able to conclude that bequest motives are one factor moderating the wealth decumulation and dissaving of the retired elderly in Italy. Needless to say, we do not include the two bequest-related variables simultaneously because of the high correlation between them.

\subsubsection{Precautionary saving-related variable}

A dummy variable that takes a value of one if the respondent holds at least one insurance product (life insurance, private health insurance, or insurance-based saving) and zero otherwise.

If this variable is regarded as a proxy for respondents' degree of risk aversion, we would expect respondents holding at least one insurance product to be more 
risk-averse, to engage in more precautionary saving, and therefore to decumulate their wealth more slowly. Thus, if ownership of insurance products is found to have a positive and significant impact on households' wealth accumulation rate, as expected, we will be able to conclude that precautionary saving is one explanation of the slower than expected wealth decumulation rates of the retired elderly in Italy.

\subsubsection{Control variables}

Learning from Alessie et al. (1995, 1999), we include a large number of control variables including those relating to the respondent's age, age squared, gender, marital status, and educational attainment and the household's wealth (net worth), housing type, the number of non-cohabiting children, and city size (whether or not the respondent lives in a city with a population of 500,000 or more). The reference category for marital status is widowed, that for educational attainment is no schooling, and that for housing type is occupied in usufruct (temporary right to occupy) or occupied free of charge. We also include regional dummies for Northern Italy (Piemonte, Valle d'Aosta, Lombardia, Liguria, Trentino Alto Adige, Veneto, Friuli Venezia Giulia, and Emilia Romagna) and Central Italy (Toscana, Marche, Umbria, and Lazio), with the reference category being Southern Italy and Islands (Abruzzo, Molise, Campania, Puglia, Calabria, Basilicata, Sicilia, and Sardegna). We will not discuss these control variables in detail due to space limitations.

Note finally that there is the possibility of endogeneity, omitted variables, or reverse causality between wealth accumulation rates and bequest intentions. For example, it could be that there is an omitted variable (e.g., greater retirement needs) that is leading to higher wealth accumulation rates as well as to weaker bequest intentions and lower intended bequest to wealth ratios, thereby causing a downward bias in the coefficient of the bequest-related variables. We therefore also try estimating our wealth accumulation rate equation using two-stage least squares (TSLS) in addition to estimating it using ordinary least squares (OLS). We use the receipt of bequests and inter vivos transfers and the expectation of receiving bequests and inter vivos transfers as instruments for both bequest intentions and the intended bequest to wealth ratio (which are never included together as explanatory variables, as discussed earlier) because they are not necessarily correlated with wealth accumulation rates but are likely to be correlated with bequests intentions (for example, Niimi and Horioka 2018, find that those who receive bequests and inter vivos transfers are significantly more likely to leave bequests than those who did not receive bequests and inter vivos transfers in both Japan and the United States, as do Cannari and D'Alessio 2008, in the case of Italy). The usual tests confirm that these instruments are not weak and that they are not correlated with the residuals.

\subsection{The estimation model for the regressions based on data from the 2012-2014 waves}

\subsubsection{Dependent variables}

We use the same two dependent variables that we use in our analysis of data from the 2000-2002 waves for our analysis of data from the 2012-2014 waves. 


\subsubsection{Bequest-related variables}

We had no choice but to use different bequest-related variables from those used in our analysis based on data from the 2000-2002 waves because information on bequest intentions and the intended value of bequests is not available in the 2012 and 2014 waves. Information is available on whether or not respondents have received bequests and inter vivos transfers in the past, and since Niimi and Horioka (2018) found that those who receive bequests are significantly more likely to leave bequests themselves than those who did not receive bequests, as did Cannari and D'Alessio (2008) in the case of Italy, we used the following variable as a proxy for bequest intentions.

(1) A dummy variable that takes a value of one if the respondent has received a bequest or inter vivos transfer in the past and zero otherwise.

Moreover, since information is collected on respondents' saving motives in the 2014 wave (respondents are asked to select their three most important motives for saving from among 10 choices), we include the following variables as proxies for bequest intentions in our saving regressions:

(1) A dummy variable that takes a value of one if the respondent is saving to give inter vivos transfers to children and grandchildren (i.e., to pay for their education and economic support) and zero otherwise.

(2) A dummy variable that takes a value of one if the respondent is saving in order to leave bequests to children and grandchildren and zero otherwise.

If these bequest-related variables are found to have a positive and significant impact on the wealth accumulation rates and saving amounts of the retired elderly in Italy, this can be construed as corroborative evidence that bequest motives are one factor moderating the wealth decumulation and dissaving of the retired elderly in Italy.

\subsubsection{Precautionary saving-related variables}

We were able to include three variables relating to precautionary saving because of the availability of data on saving motives:

(1) The same dummy variable for ownership of insurance products that we use in the case of our analysis based on data from the 2000-2002 waves.

(2) A dummy variable that takes a value of one if the respondent is saving for old age and zero otherwise.

(3) A dummy variable that takes a value of one if the respondent is saving for unexpected contingencies and zero otherwise.

If insurance ownership and/or saving for old age and for unexpected contingencies are found to have a positive and significant impact on the wealth accumulation and saving behavior of the retired elderly in Italy, as expected, we will be able to conclude that saving for precautionary saving is one explanation for the less prevalent than expected wealth decumulation and saving of the retired elderly in Italy. 
Unfortunately, however, the variables relating to saving motives could be included only in the regressions for the amount of saving because information on these variables was collected only in the 2014 wave.

\subsubsection{Control variables}

We include the same control variables that we include in the case of our analysis based on data from the 2000-2002 waves.

\section{Data source and sample selection}

In this section, we explain the data source and sample selection criteria we use for our analysis. The data set we use is the "Survey of Italian Households' Income and Wealth (hereafter SHIW)," which has been conducted by the Bank of Italy since 1965 (and as a panel survey since 1989). This data set is ideally suited for the topic of this paper because it includes detailed data on the flow of saving, the stock of wealth (net worth), bequest intentions, the value of the intended bequest, saving motives, preference parameters such as those relating to time preference and risk aversion, demographic and economic characteristics, etc.

Each wave of the Survey, which has been conducted as a panel every two years since 1989, collects information on about 8000 households randomly chosen from population registers (attrition hovers around $20 \%$ per wave). The Survey is very rich and collects information on virtually every aspect of households' lives, including social and demographic characteristics (such as age, gender, educational attainment, type of job, number of income earners, dynamics of the household in terms of members entering and leaving, information about parents and spouse's parents, etc.), consumption (including detailed breakdown by type), income, gross and net wealth, and categories thereof.

Importantly, some waves of the SHIW include special sections devoted to particular aspects of households' lives, and we were drawn to the 2002 and 2014 waves of the survey because the 2002 wave included a special section on intergenerational transfers, with information on bequests and inter vivos transfers received, bequest intentions, and the amount of intended bequests, and because the 2012 wave asked about bequests and inter vivos transfers received as well as about saving motives. ${ }^{1}$

Since data from two consecutive waves are needed to calculate the wealth accumulation rate, we used the 2000-2002 and 2012-2014 waves to calculate the wealth accumulation rate, but we used the values of the explanatory variables in the earlier of the two waves (2000 and 2012, respectively) in order to mitigate potential endogeneity issues. The only exception to this rule was that we had to use the 2002 and 2014 values of the bequest-related variables because these variables were not available in 2000 or 2012 . However, we do not believe that this will seriously bias our results because these variables pertain to intentions and preferences and are therefore presumably relatively stable over time.

\footnotetext{
${ }^{1}$ More details about this Survey can be found at the following url: https://www.bancaditalia.it/statistiche/ tematiche/indagini-famiglie-imprese/bilanci-famiglie/distribuzione-microdati/index.html
} 
By contrast, since the amount of saving could be calculated from just one wave of data, the saving regressions were estimated using cross-sections of the 2002 and 2014 waves to benefit from a much larger number of observations, and thus the control variables refer to the same year. However, since the control variables are mostly sociodemographic and geographic variables that are relatively stable over the short time span used for our analysis, we do not believe that our procedure will introduce any serious biases in our results.

We confine our sample to only single-person or couple households in which both the husband and wife are 60 or older and retired to avoid the problem of having to allocate saving, wealth, etc., to cohabiting household members. We also confine our sample to households with at least one non-cohabiting child since we are interested in looking at the impact of bequest intentions on wealth accumulation behavior and since respondents with no living children are unlikely to have a bequest motive. We also drop observations for which all of the necessary information is not available as well as observations whose wealth accumulation rate is less than $-200 \%$ or more than $300 \%$ in order to purge the sample of outliers.

These conditions, in particular the condition that no household member works, greatly reduced the size of the sample and left us with only 302 observations in the 2000-2002 waves and 1041 observations in the 2012-2014 waves for our analysis of the wealth accumulation rate and with 790 or 664 observations for the 2002 wave (depending on which variables are included) and 2328 observations for the 2014 wave for our analysis of the amount of saving. We should note, however, that sample weights provided by the Bank of Italy were always used for both the descriptive statistics and the regressions to ensure that our sample remained representative of the universe of households fulfilling the aforementioned criteria.

Special care has been taken to construct a measure of the change in wealth that includes only out-of-pocket saving and excludes capital gains and losses on real estate, equities, and bonds. Real estate, which constitutes the bulk of wealth (net worth), is evaluated at constant prices to avoid the risk of including positive (or negative) changes in wealth that are due solely to housing price inflation or deflation. To obtain the value of real estate at constant prices, real estate in 2002 and 2014 was valued at 2000 and 2012 prices whenever possible (i.e., whenever the same property was owned in both periods) and deflated by a real estate deflator otherwise. ${ }^{2}$ In fact, the former method was applied to 75\% of households in the 2000-2002 panel and to about $80 \%$ of households in the larger 2012-2014 panel. For these households, therefore, changes in net worth are due entirely to changes in holdings of financial assets and liabilities. Equities and (in the case of the analysis based on data from the 2012-2014 waves) bonds were also evaluated at constant prices for the same reason. ${ }^{3}$ All other components of wealth (net worth) in 2002 were deflated using the consumer price index.

\footnotetext{
2 The Real Property Price Index of the European Central Bank was used, and data on this index were taken from http://sdw.ecb.europa.eu/quickview.do?SERIES_KEY=129.RPP.A.IT.N.TD.00.2.00

3 The FTSE MIB, the primary benchmark index for Italian equity markets, and FTSE MTS, an index for Italian government bonds with a maturity of one to three years, were used, and data on these indices were taken from https://www.borsaitaliana.it/borsa/indici/indici-in-continua/dettaglio.html?indexCode=FTSEMIB\&lang=it and https://it.investing.com/indices/ftse-mts-italy-government-1-3y-chart, respectively.
} 
Table 1 Descriptive statistics for all variables, 2000-2002 waves

\begin{tabular}{|c|c|c|c|c|c|c|}
\hline Variable & Obs. & Median & Mean & Std. dev. & Min & $\operatorname{Max}$ \\
\hline Bequest intentions & 302 & 1.000 & 0.507 & 0.038 & 0.000 & 1.000 \\
\hline Value of intended bequest $(10,000$ euros $)$ & 302 & 0.000 & 8.291 & 1.015 & 0.000 & 118.687 \\
\hline Intended bequest to wealth ratio & 302 & 0.000 & 0.565 & 0.055 & 0.000 & 5.344 \\
\hline Insurance & 302 & 0.000 & 0.089 & 0.285 & 0.000 & 1.000 \\
\hline Bequests receipts & 302 & 0.000 & 0.145 & 0.025 & 0.000 & 1.000 \\
\hline Bequest expectations & 302 & 0.000 & 0.029 & 0.010 & 0.000 & 1.000 \\
\hline Household head's age & 302 & 73.000 & 73.536 & 0.611 & 61.000 & 99.000 \\
\hline Household head's age $* * 2 / 100$ & 302 & 53.290 & 54.628 & 0.923 & 37.210 & 98.010 \\
\hline Male & 302 & 1.000 & 0.551 & 0.038 & 0.000 & 1.000 \\
\hline Married & 302 & 1.000 & 0.540 & 0.038 & 0.000 & 1.000 \\
\hline Single & 302 & 0.000 & 0.005 & 0.003 & 0.000 & 1.000 \\
\hline Separated/divorced & 302 & 0.000 & 0.042 & 0.017 & 0.000 & 1.000 \\
\hline Number of non-cohabiting children & 302 & 2.000 & 2.267 & 1.197 & 1.000 & 8.000 \\
\hline No schooling & 302 & 0.000 & 0.157 & 0.033 & 0.000 & 1.000 \\
\hline Elementary school & 302 & 1.000 & 0.606 & 0.038 & 0.000 & 1.000 \\
\hline Middle school & 302 & 0.000 & 0.116 & 0.022 & 0.000 & 1.000 \\
\hline Vocational secondary school & 302 & 0.000 & 0.020 & 0.009 & 0.000 & 1.000 \\
\hline High school & 302 & 0.000 & 0.071 & 0.018 & 0.000 & 1.000 \\
\hline Post-secondary & 302 & 0.000 & 0.031 & 0.010 & 0.000 & 1.000 \\
\hline Homeowner & 302 & 1.000 & 0.747 & 0.035 & 0.000 & 1.000 \\
\hline Renter & 302 & 0.000 & 0.124 & 0.025 & 0.000 & 1.000 \\
\hline Redemption (renting with option to buy) & 302 & 0.000 & 0.004 & 0.004 & 0.000 & 1.000 \\
\hline Major city & 302 & 0.000 & 0.086 & 0.024 & 0.000 & 1.000 \\
\hline North & 302 & 0.000 & 0.436 & 0.497 & 0.000 & 1.000 \\
\hline Central & 302 & 0.000 & 0.161 & 0.369 & 0.000 & 1.000 \\
\hline Wealth in 2000 (10,000 euros) & 302 & 8.883 & 13.328 & 1.111 & -0.258 & 173.530 \\
\hline Wealth accumulation rate, 2000-2002 (\%) & 302 & -2.341 & -7.515 & 3.875 & -100.000 & 270.188 \\
\hline $\begin{array}{l}\text { Saving in } 2002 \text { at } 2000 \text { 's prices } \\
(10,000 \text { euros })\end{array}$ & 302 & 0.196 & 0.383 & 0.047 & -1.332 & 3.673 \\
\hline
\end{tabular}

Source: Bank of Italy, Survey of Italian Households' Income and Wealth

\section{Descriptive statistics}

In this section, we present and discuss some descriptive statistics. Table 1 shows descriptive statistics (medians, means, standard deviations, and minimum and maximum values) for all dependent and explanatory variables used in our regression analysis. In what follows, we will refer primarily to medians rather than to means because medians are less influenced by extreme values than are means.

As this table shows, the median wealth decumulation rate was $2.3 \%$ in $2000-2002$ and $0.6 \%$ in 2012-2014, which corresponds to an annual wealth decumulation rate of $1.2 \%$ and $0.3 \%$, respectively. Thus, the retired elderly in Italy were decumulating their wealth (dissaving) before as well as after the Global Financial Crisis of 2007-2008, as predicted by the simple life-cycle model, but their wealth 
decumulation rates are far too slow if one takes account of the fact that life expectancy at age 60 in Italy was 25 years in $2015 .^{4}$ Moreover, the wealth decumulation rate of the retired elderly in Italy was even lower in 2012-2014 than it was in 2000-2002, possibly because the increased uncertainty caused by the Global Financial Crisis caused the retired elderly in Italy to moderate their speed of wealth decumulation and dissaving even more than they had been doing previously.

Moreover, the proportion of the retired elderly with a positive wealth accumulation rate was a full $42.4 \%$ in $2000-2002$ and a full $44.1 \%$ in $2012-2014$, and the proportion of the retired elderly engaging in a positive amount of saving was a full $84.4 \%$ in 2002 and a full $89.5 \%$ in $2014 .^{5}$

All of the foregoing evidence strongly suggests that the Wealth Decumulation Puzzle applies in the case of Italy, especially after the Global Financial Crisis. This is consistent with the findings of the studies for Italy that we surveyed earlier and with the findings for most other countries also.

Table 1 also shows that the roughly half (50.7\%) of the retired elderly in Italy intend to leave bequests to their children and that intended bequests are a full $56.5 \%$ of household wealth. Both of these figures suggest that bequest motives are quite strong in Italy.

Table 2 shows the proportion of households saving for each of four saving motives, and as can be seen from this table, $15.7 \%$ of respondents are saving for inter vivos transfers and $71.4 \%$ are saving for bequests, which suggests that saving for bequests and other intergenerational transfers is important. At the same time, $54.8 \%$ of respondents are saving for unforeseen contingencies and $32.9 \%$ are saving for old age, which suggests that saving for precautionary purposes is also important.

Table 3 shows the median wealth accumulation rate in 2000-2002 and 2012-2014 broken down by the age and marital status of the household head, and as can be seen from this table, the wealth accumulation rate is negative in all age groups and all marital statuses in both time periods (except for one exception in 2012-2014), which is consistent with the simple life-cycle model. However, the wealth decumulation rate is slower than expected (except in the 81 or older age group in 2000-2002), which suggests that the Wealth Decumulation Puzzle is observed in virtually all age groups and all marital statuses. Moreover, the wealth decumulation rate is lower in 2012-2014 than in 2000-2002 in all cases except one, which further corroborates our earlier finding that the Global Financial Crisis caused the retired elderly in Italy to moderate their speed of wealth decumulation even more than they had been doing previously. Finally, Table 2 shows that the wealth decumulation rate is highest in the 81 or older age group in both time periods, which is as one would expect given that medical and long-term care expenses tend to increase with age.

\footnotetext{
${ }^{4}$ This figure is from Global Age Watch Index 2015, taken from https://www.helpage.org/global-agewa tch/population-ageing-data/life-expectancy-at-60/

${ }^{5}$ As for what sets positive savers apart from others, we compared the income and consumption of positive savers and others and found that positive savers had both higher income and lower consumption in both 2002 and 2014, but less so in 2014, when consumption levels were comparable and income drove the result. These findings suggest that dissavers dissave partly because they have lower incomes and partly because they have higher consumption and that it is relatively affluent households that are saving, which is not surprising.
} 
Table 2 Descriptive statistics for all variables, 2012-2014 waves

\begin{tabular}{|c|c|c|c|c|c|c|}
\hline Variable & Obs. & Median & Mean & Std. dev. & Min & Max \\
\hline Bequests received & 1041 & 0.000 & 0.189 & 0.015 & 0.000 & 1.000 \\
\hline Insurance & 1041 & 0.000 & 0.063 & 0.009 & 0.000 & 1.000 \\
\hline $\begin{array}{l}\text { Saving for education/economic support (inter } \\
\text { vivos transfers) to children and grandchildren }\end{array}$ & 1041 & 0.000 & 0.157 & 0.015 & 0.000 & 1.000 \\
\hline $\begin{array}{l}\text { Saving for bequests to children and } \\
\text { grandchildren }\end{array}$ & 1041 & 1.000 & 0.714 & 0.018 & 0.000 & 1.000 \\
\hline Saving for unforeseen contingencies & 1041 & 1.000 & 0.548 & 0.020 & 0.000 & 1.000 \\
\hline Saving for old age needs & 1041 & 0.000 & 0.329 & 0.019 & 0.000 & 1.000 \\
\hline Household head's age & 1041 & 76.000 & 75.605 & 0.311 & 60.000 & 101.000 \\
\hline Household head's age**2/100 & 1041 & 57.760 & 57.786 & 0.477 & 36.000 & 102.010 \\
\hline Male & 1041 & 0.000 & 0.460 & 0.020 & 0.000 & 1.000 \\
\hline Married & 1041 & 1.000 & 0.513 & 0.020 & 0.000 & 1.000 \\
\hline Single & 1041 & 0.000 & 0.001 & 0.001 & 0.000 & 1.000 \\
\hline Separated/divorced & 1041 & 0.000 & 0.056 & 0.009 & 0.000 & 1.000 \\
\hline Number of non-cohabiting children & 1041 & 2.000 & 2.161 & 0.042 & 1.000 & 7.000 \\
\hline No schooling & 1041 & 0.000 & 0.112 & 0.014 & 0.000 & 1.000 \\
\hline Elementary school & 1041 & 0.000 & 0.422 & 0.020 & 0.000 & 1.000 \\
\hline Middle school & 1041 & 0.000 & 0.216 & 0.016 & 0.000 & 1.000 \\
\hline Vocational secondary school & 1041 & 0.000 & 0.058 & 0.009 & 0.000 & 1.000 \\
\hline High school & 1041 & 0.000 & 0.128 & 0.012 & 0.000 & 1.000 \\
\hline Post-secondary & 1041 & 0.000 & 0.063 & 0.010 & 0.000 & 1.000 \\
\hline Homeowner & 1041 & 1.000 & 0.773 & 0.017 & 0.000 & 1.000 \\
\hline Renter & 1041 & 0.000 & 0.111 & 0.013 & 0.000 & 1.000 \\
\hline Redemption (renting with option to buy) & 1041 & 0.000 & 0.002 & 0.001 & 0.000 & 1.000 \\
\hline Residing in a major city & 1041 & 0.000 & 0.086 & 0.013 & 0.000 & 1.000 \\
\hline North & 1041 & 0.000 & 0.422 & 0.019 & 0.000 & 1.000 \\
\hline Central & 1041 & 0.000 & 0.186 & 0.016 & 0.000 & 1.000 \\
\hline Wealth in 2012 (10,000 euros) & 1041 & 16.550 & 25.133 & 1.396 & -1.413 & 569.695 \\
\hline Wealth in 2014 (10,000 euros) & 1041 & 16.932 & 24.150 & 1.274 & -0.067 & 573.454 \\
\hline Wealth accumulation rate, 2012-2014 & 1041 & -0.568 & 2.014 & 2.544 & 164.871 & 291.546 \\
\hline Amount of saving in 2014 ( 10,000 euros) & 1041 & 0.350 & 0.526 & 0.028 & -3.541 & 5.973 \\
\hline
\end{tabular}

Source: Bank of Italy, Survey of Italian Households' Income and Wealth

We then tried calculating median wealth accumulation rates by various attributes such as bequest intentions, the intended bequest to wealth ratio, and insurance ownership.

First, we calculated the median wealth accumulation rate for respondents with and without bequest intentions and found that it is $6.4 \%$ for those with bequest intentions and $-22.1 \%$ for those without such intentions, a gap of a full 28.5 percentage points.

Next, we calculated the median wealth accumulation rate by quintile of the intended bequest to wealth ratio and found that the median wealth accumulation rate increases with the intended bequest to wealth ratio, as expected, from $-21.7 \%$ in 
Table 3 Median wealth accumulation rates by age and marital status

\begin{tabular}{|c|c|c|c|c|}
\hline & \multicolumn{2}{|c|}{ 2000-2002 } & \multicolumn{2}{|c|}{ 2012-2014 } \\
\hline & $\begin{array}{l}\text { No. } \\
\text { of obs. }\end{array}$ & $\begin{array}{l}\text { Median wealth } \\
\text { accumulation rate }\end{array}$ & $\begin{array}{l}\text { No. } \\
\text { of obs. }\end{array}$ & $\begin{array}{l}\text { Median wealth } \\
\text { accumulation rate }\end{array}$ \\
\hline \multicolumn{5}{|l|}{ Age group } \\
\hline $60-70$ & 113 & -2.34 & 333 & -0.23 \\
\hline $71-80$ & 133 & -1.38 & 430 & -0.56 \\
\hline 81 or older & 56 & -6.43 & 278 & -1.76 \\
\hline \multicolumn{5}{|l|}{ Marital status } \\
\hline Single & 3 & -1.38 & 2 & 0.63 \\
\hline Married & 175 & -1.96 & 578 & -0.97 \\
\hline Separate/divorced & 10 & -0.11 & 56 & -1.11 \\
\hline Widowed & 114 & -2.67 & 405 & -1.22 \\
\hline Full sample & 302 & -2.34 & 1041 & -0.57 \\
\hline
\end{tabular}

Source: Bank of Italy, Survey of Households' Income and Wealth

the lowest quintile to $24.5 \%$ in the highest quintile, a gap of a full 46.4 percentage points.

Finally, we calculated the median wealth accumulation rate for respondents who own an insurance product and those who do not, and found that it is $1.5 \%$ for those who own an insurance product and $-2.6 \%$ for those who do not, a gap of 4.1 percentage points. This suggests that saving for precautionary purposes may be somewhat important in the case of the retired elderly in Italy.

Thus, our descriptive statistics suggest that both bequest motives and precautionary saving are important in the case of Italy and that both appear to have a substantial impact on the wealth accumulation and saving behavior of the retired elderly in Italy, especially the former, but we need to do a regression analysis to determine whether these results hold even after controlling for other variables.

\section{Estimation results}

\subsection{Estimation results based on data from the 2000-2002 waves}

In this section, we present the estimation results of our regression analysis of the determinants of the wealth accumulation and saving behavior of the retired elderly in Italy based on data from the 2000-2002 waves. The results for the wealth accumulation rate are show in Tables 4 and 5 (the ordinary least squares (OLS) results in Table 4 and the two-stage least squares (TSLS) results in Table 5), whereas the results for the amount of saving are shown in Table 6.

Looking first at the impact of bequest intentions and the intended bequest to wealth ratio, Tables 4 and 5 show that both bequest intentions and the intended bequest to wealth ratio have a positive and statistically significant impact on the wealth accumulation rate in the OLS estimates as well as in the TSLS estimates, as 
Table 4 The determinants of the wealth accumulation rate, 2000-2002 waves (ordinary least squares estimates)

\begin{tabular}{|c|c|c|c|}
\hline & $\begin{array}{l}\text { Wealth accumulation } \\
\text { rate, 2000-2002 } \\
\text { (percent) }\end{array}$ & $\begin{array}{l}\text { Wealth accumulation } \\
\text { rate, 2000-2002 } \\
\text { (percent) }\end{array}$ & $\begin{array}{l}\text { Wealth accumulation } \\
\text { rate, 2000-2002 } \\
\text { (percent) }\end{array}$ \\
\hline Bequest intentions & $13.951(6.288)^{* *}$ & & \\
\hline Bequest intentions $(\geq 60,<65)$ & & & $59.635(14.892)^{* * *}$ \\
\hline Bequest intentions $(\geq 65,<70)$ & & & $18.588(10.269)^{*}$ \\
\hline Bequest intentions $(\geq 70,<75)$ & & & $8.760(11.654)$ \\
\hline Bequest intentions $(\geq 75)$ & & & $-8.839(9.637)$ \\
\hline $\begin{array}{l}\text { Intended bequest to } \\
\text { wealth ratio }\end{array}$ & & $16.323(4.555)^{* * *}$ & \\
\hline Insurance & $7.728(12.055)$ & $8.930(11.684)$ & $10.210(12.424)$ \\
\hline Household head's age & $9.047(5.595)$ & $8.492(5.638)$ & $19.277(20.754)$ \\
\hline Household head's age $* * 2 / 100$ & $-6.457(3.748)^{*}$ & $-6.069(3.783)$ & $-12.644(14.556)$ \\
\hline Male & $-4.490(7.438)$ & $-5.677(7.546)$ & $-12.933(7.866)$ \\
\hline Married & $-10.010(8.813)$ & $-9.378(8.590)$ & $-0.300(10.204)$ \\
\hline Single & $10.389(26.744)$ & $11.485(23.729)$ & $7.187(22.979)$ \\
\hline Separated/divorced & $-40.910(18.373)^{* *}$ & $-40.258(18.190) * *$ & $-36.796(17.812)^{* *}$ \\
\hline $\begin{array}{l}\text { Number of non-cohabiting } \\
\text { children }\end{array}$ & $0.693(2.701)$ & $1.533(2.815)$ & $0.900(2.622)$ \\
\hline Elementary school & $-7.043(11.730)$ & $-6.821(11.742)$ & $-28.687(16.906)^{*}$ \\
\hline Middle school & $32.101(14.676)^{* *}$ & $31.816(14.972)^{* *}$ & $16.682(19.121)$ \\
\hline Vocational secondary school & $11.510(18.028)$ & $5.615(17.051)$ & $-32.284(28.411)$ \\
\hline High school & $16.571(18.724)$ & $8.211(18.636)$ & $-7.112(27.032)$ \\
\hline Post-secondary & $-1.485(14.739)$ & $0.338(14.247)$ & $-20.133(22.883)$ \\
\hline Homeowner & $49.184(13.724)^{* * *}$ & $46.027(13.465)^{* * *}$ & $24.814(21.238)$ \\
\hline Renter & $7.105(19.515)$ & $6.541(19.360)$ & $-24.580(24.476)$ \\
\hline $\begin{array}{l}\text { Redemption (renting with } \\
\text { option to buy) }\end{array}$ & $32.740(17.589)^{*}$ & $33.297(17.212)^{*}$ & $24.479(23.335)$ \\
\hline Major city & $-1.297(16.321)$ & $0.529(16.402)$ & $-3.069(16.077)$ \\
\hline North & $5.704(7.570)$ & $8.224(7.370)$ & $11.772(7.273)$ \\
\hline Central & $19.581(9.534)^{* *}$ & $18.799(9.433)^{* *}$ & $11.058(7.554)$ \\
\hline $\begin{array}{l}\text { Wealth in } 2000 \text { (in } \\
10,000 \text { euros) }\end{array}$ & $-0.515(0.152)^{* * *}$ & $-0.426(0.134)^{* * *}$ & $-0.449(0.168)^{* * *}$ \\
\hline Constant & $-357.047(205.275)^{*}$ & $-340.657(206.463)$ & $-730.965(737.572)$ \\
\hline$R^{2}$ & 0.30 & 0.33 & 0.31 \\
\hline$N$ & 302 & 302 & 246 \\
\hline
\end{tabular}

$* p<0.1 ; * * p<0.05 ; * * * p<0.01$

expected. In fact, the coefficients of both bequest intentions and the intended bequest to wealth ratio are larger and more significant in the TSLS estimates, suggesting that the impact of bequests on wealth accumulation rates is robust and even stronger after controlling for endogeneity, omitted variable bias, and reverse causality. Indeed, the direction of the OLS bias suggests that an omitted variable (e.g., greater retirement needs) is leading to higher wealth accumulation rates as well as to weaker bequest 
Table 5 The determinants of the wealth accumulation rate, 2000-2002 (two-stage least squares estimates)

\begin{tabular}{|c|c|c|}
\hline & $\begin{array}{l}\text { Wealth accumulation rate, } \\
2000-2002 \text { (percent) }\end{array}$ & $\begin{array}{l}\text { Wealth accumulation rate, } \\
\text { 2000-2002 (percent) }\end{array}$ \\
\hline Bequest intentions & $54.726(27.756)^{* *}$ & \\
\hline $\begin{array}{l}\text { Intended bequest to } \\
\text { wealth ratio }\end{array}$ & & $34.210(15.023)^{* *}$ \\
\hline Insurance & $8.280(12.776)$ & $10.453(12.022)$ \\
\hline Household head's age & $8.710(5.970)$ & $7.757(5.717)$ \\
\hline Household head's age $* * 2 / 100$ & $-6.287(4.033)$ & $-5.580(3.835)$ \\
\hline Male & $-5.164(8.616)$ & $-7.230(8.384)$ \\
\hline Married & $-15.618(9.304)^{*}$ & $-10.787(8.747)$ \\
\hline Single & $-11.033(31.011)$ & $4.655(21.763)$ \\
\hline Separated/divorced & $-33.046(18.515)^{*}$ & $-36.595(17.726)^{* *}$ \\
\hline Elementary school & $-11.929(12.804)$ & $-8.410(12.131)$ \\
\hline Middle school & $36.610(16.611)^{* *}$ & $33.194(15.587)^{* *}$ \\
\hline Vocational secondary school & $3.199(18.196)$ & $-3.961(18.184)$ \\
\hline High school & $5.766(21.131)$ & $-5.000(23.155)$ \\
\hline Post-secondary & $-13.664(19.876)$ & $-2.229(14.836)$ \\
\hline $\begin{array}{l}\text { Number of non-cohabiting } \\
\text { children }\end{array}$ & $2.079(3.348)$ & $2.973(3.370)$ \\
\hline Homeowner & $31.142(18.186)^{*}$ & $35.803(14.795)^{* *}$ \\
\hline Renter & $9.254(18.621)$ & $6.729(18.563)$ \\
\hline $\begin{array}{l}\text { Redemption (renting with } \\
\text { option to buy) }\end{array}$ & $-2.685(28.530)$ & $20.627(18.978)$ \\
\hline North & $-0.006(8.947)$ & $8.845(7.564)$ \\
\hline Central & $13.141(11.560)$ & $15.526(10.064)$ \\
\hline Major city & $-2.330(15.324)$ & $2.142(15.792)$ \\
\hline $\begin{array}{l}\text { Wealth in } 2000 \text { (in } \\
10,000 \text { euros) }\end{array}$ & $-0.496(0.163)^{* * *}$ & $-0.322(0.171)^{*}$ \\
\hline Constant & $-341.742(217.271)$ & $-316.961(209.944)$ \\
\hline$R^{2}$ & 0.20 & 0.28 \\
\hline$N$ & 302 & 302 \\
\hline
\end{tabular}

$* p<0.1 ; * * p<0.05 ; * * * p<0.01$

intentions and lower intended bequest to wealth ratios, which in turn is leading to a downward bias in the coefficients of the bequest-related variables in the OLS regressions.

As for how the impact of bequest intentions on the wealth accumulation rate of the retired elderly in Italy compares to that for other countries, the OLS coefficient for Italy is lower than the OLS coefficient for Japan in a very similar study (Niimi and Horioka 2019), but the TSLS coefficient for Italy is higher. ${ }^{6}$ This suggests that the impact of bequest intentions is roughly comparable in the two other countries, which

\footnotetext{
${ }^{6}$ Niimi and Horioka (2019) distinguish between those intending to leave bequests for altruistic reasons and those intending to leave bequests for strategic reasons, but the above conclusions are unchanged regardless of the type of bequest motive.
} 
Table 6 The determinants of the amount of saving, 2000-2002 waves (ordinary least squares estimates)

\begin{tabular}{|c|c|c|}
\hline & $\begin{array}{l}\text { Amount of saving in } 2002 \text { at } 2000 \\
\text { prices (in 10,000 euros) }\end{array}$ & $\begin{array}{l}\text { Amount of saving in } 2002 \text { at } 2000 \\
\text { prices (in } 10,000 \text { euros) }\end{array}$ \\
\hline Bequest intentions & $0.067(0.034)^{*}$ & \\
\hline $\begin{array}{l}\text { Intended bequest to } \\
\text { wealth ratio }\end{array}$ & & $-0.005(0.021)$ \\
\hline Insurance & $0.135(0.092)$ & $0.175(0.099)^{*}$ \\
\hline Household head's age & $0.015(0.026)$ & $0.005(0.027)$ \\
\hline Household head's age**2/100 & $-0.010(0.017)$ & $0.003(0.017)$ \\
\hline Male & $0.033(0.036)$ & $-0.005(0.039)$ \\
\hline Married & $0.090(0.040)^{* *}$ & $0.127(0.044) * * *$ \\
\hline Single & $0.092(0.153)$ & $0.084(0.137)$ \\
\hline Separated/divorced & $-0.119(0.052)^{* *}$ & $-0.109(0.068)$ \\
\hline $\begin{array}{l}\text { Number of non-cohabiting } \\
\text { children }\end{array}$ & $0.001(0.011)$ & $0.001(0.012)$ \\
\hline Elementary school & $0.019(0.030)$ & $-0.007(0.031)$ \\
\hline Middle school & $0.110(0.047)^{* *}$ & $0.111(0.052)^{* *}$ \\
\hline Vocational secondary school & $0.103(0.118)$ & $0.153(0.114)$ \\
\hline High school & $0.155(0.071)^{* *}$ & $0.127(0.076)^{*}$ \\
\hline Post-secondary & $0.529(0.127)^{* * *}$ & $0.522(0.138)^{* * *}$ \\
\hline Homeowner & $0.047(0.039)$ & $0.074(0.042)^{*}$ \\
\hline Renter & $-0.118(0.044)^{* * *}$ & $-0.149(0.047)^{* * *}$ \\
\hline $\begin{array}{l}\text { Redemption (renting with } \\
\text { intention to buy) }\end{array}$ & $-0.122(0.099)$ & $-0.111(0.104)$ \\
\hline Major city & $0.029(0.041)$ & $0.009(0.046)$ \\
\hline North & $0.130(0.032)^{* * *}$ & $0.158(0.035)^{* * *}$ \\
\hline Central & $-0.009(0.034)$ & $-0.013(0.034)$ \\
\hline $\begin{array}{l}\text { Wealth in } 2002 \text { at } 2000 \text { prices } \\
\text { (in } 10,000 \text { euros) }\end{array}$ & $-0.000(0.002)$ & $-0.000(0.002)$ \\
\hline Constant & $-0.489(1.019)$ & $-0.088(1.049)$ \\
\hline$R^{2}$ & 0.23 & 0.26 \\
\hline$N$ & 790 & 664 \\
\hline
\end{tabular}

$* p<0.1 ; * * p<0.05 ; * * * p<0.01$

is reassuring because the two countries are similar in many ways (e.g., close family ties, aged populations, traditionally high saving rates, etc.).

We then tried replacing the bequest intentions variable with interactive terms between bequest intentions and age group dummies to see whether or not the impact of bequest intentions on the wealth accumulation rate varies by age. The results are shown in the last column of Table 4, and as can be seen from this column, the impact of bequest intentions varies greatly by age, with its impact being the largest and most statistically significant in the 60-64 age group, smaller but still statistically significant in the 65-69 age group, and not statistically significant in the 70-74 and 75 or older age groups. Our finding that the impact of bequest intentions on the wealth accumulation rate declines sharply with age is new but not surprising because, as 
people age, their medical and long-term care expenses tend to increase, making it increasingly difficult to moderate wealth decumulation even if they have a bequest motive.

Looking next at the impact of bequests on the amount of saving, Table 6 shows that bequest intentions have a positive and statistically significant impact on the amount of saving but that the intended bequest to wealth ratio does not have a statistically significant impact thereon. Thus, almost all of our results suggest that bequest motives are one explanation for the lower than expected wealth decumulation rates and dissaving of the retired elderly in Italy.

Turning next to the impact of insurance ownership, it does not have a statistically significant impact on the wealth accumulation rate in either the OLS or TSLS estimates, perhaps because we have not adequately controlled for the endogeneity of insurance ownership. However, insurance ownership has a positive and statistically significant impact on the amount of saving, as expected. This constitutes weak evidence that saving for precautionary purposes is one explanation for why the retired elderly in Italy dissave less than expected.

Turning finally to the impact of the control variables, and looking first at their impact on the wealth accumulation rate, separated or divorced respondents seem to have significantly lower wealth accumulation rates, homeowner households seem to have significantly higher wealth accumulation rates, and wealth seems to have a negative and statistically significant impact on the wealth accumulation rate. As for the impact of the control variables on the amount of saving, married and more highly educated respondents and respondents living in the North seem to have significantly higher amounts of saving.

\subsection{Estimation results based on data from the 2012-2014 waves}

In this section, we present the estimation results of our regression analysis of the determinants of the wealth accumulation rate and saving behavior of the retired elderly in Italy based on data from the 2012-2014 waves. The results for the wealth accumulation rate are show in the first column of Table 7 whereas the results for saving are shown in the second column of the same table.

Looking first at bequest-related variables, bequest receipts (which are included as a proxy for bequest intentions) are found to have a positive and statistically significant impact on the wealth accumulation rate. Bequest receipts are found not to have a statistically significant impact on the amount of saving, but dummy variables for saving for inter vivos transfers and saving for bequests (which are included to capture the impact of bequest motives) are both found to have a positive and statistically significant impact on the amount of saving. These results provide further corroboration that the lower than expected wealth accumulation and dissaving of the retired elderly in Italy are due largely to bequest motives.

Turning next to the impact of precautionary saving-related variables and looking first at the impact of insurance ownership, it is found not to have a statistically significant impact on the wealth accumulation rate but is found to have a positive and statistically significant impact on saving, as in the case of the results based on the 2000-2002 waves. These results provide further (weak) corroboration that saving for 
Table 7 The determinants of the wealth accumulation rate and saving, 2012-2014 (ordinary least squares estimates)

\begin{tabular}{|c|c|c|c|}
\hline & $\begin{array}{l}\text { Wealth accumulation } \\
\text { rate, 2012-2014 } \\
\text { (percent) }\end{array}$ & $\begin{array}{l}\text { Saving in } 2014 \text { at } \\
2012 \text { prices (in } \\
10,000 \text { euros) }\end{array}$ & $\begin{array}{l}\text { Saving in } 2014 \text { at } \\
2012 \text { prices (in } \\
10,000 \text { euros) }\end{array}$ \\
\hline Bequest receipts & $12.131(7.097)^{*}$ & $-0.025(0.060)$ & $-0.038(0.061)$ \\
\hline Insurance & $-9.146(5.683)$ & $0.380(0.161)^{* *}$ & $0.390(0.161)^{* * *}$ \\
\hline $\begin{array}{l}\text { Saving for inter vivos } \\
\text { transfers }\end{array}$ & & $0.134(0.050)^{* * *}$ & $0.151(0.051)^{* * *}$ \\
\hline Saving for bequests & & $0.104(0.039)^{* * *}$ & $0.134(0.042) * * *$ \\
\hline $\begin{array}{l}\text { Saving for unforeseen } \\
\text { contingencies }\end{array}$ & & & $0.122(0.047)^{* * *}$ \\
\hline Saving for old age & & & $0.035(0.039)$ \\
\hline Household head's age & $-5.605(5.432)$ & $0.031(0.033)$ & $0.032(0.033)$ \\
\hline Household head's age $* * 2 / 100$ & $3.229(3.565)$ & $-0.020(0.021)$ & $-0.020(0.021)$ \\
\hline Male & $9.862(5.947)^{*}$ & $0.082(0.052)$ & $0.086(0.052)$ \\
\hline Married & $-4.339(5.455)$ & $0.203(0.054)^{* * *}$ & $0.194(0.055)^{* * * *}$ \\
\hline Single & $-3.495(9.319)$ & $-0.017(0.139)$ & $-0.034(0.137)$ \\
\hline Separated/divorced & $-3.309(14.003)$ & $0.046(0.168)$ & $0.048(0.168)$ \\
\hline Elementary school & $10.483(13.506)$ & $-0.082(0.037)^{* *}$ & $-0.090(0.037)^{* *}$ \\
\hline Middle school & $0.937(15.638)$ & $-0.002(0.082)$ & $-0.011(0.082)$ \\
\hline Vocational secondary school & $0.845(15.708)$ & $-0.073(0.101)$ & $-0.076(0.101)$ \\
\hline High school & $9.963(15.751)$ & $0.100(0.143)$ & $0.088(0.143)$ \\
\hline Post-secondary & $21.577(15.908)$ & $0.442(0.288)$ & $0.439(0.285)$ \\
\hline $\begin{array}{l}\text { Number of non-cohabiting } \\
\text { children }\end{array}$ & $1.941(2.477)$ & $-0.017(0.011)$ & $-0.019(0.011)^{*}$ \\
\hline Homeowner & $20.268(13.627)$ & $0.017(0.102)$ & $0.025(0.102)$ \\
\hline Renter & $13.401(18.513)$ & $-0.274(0.060)^{* * *}$ & $-0.260(0.060)^{* * *}$ \\
\hline $\begin{array}{l}\text { Redemption (renting with } \\
\text { option to buy) }\end{array}$ & $79.826(59.651)$ & $0.028(0.131)$ & $0.026(0.120)$ \\
\hline North & $0.650(6.312)$ & $0.195(0.049)^{* * *}$ & $0.197(0.049)^{* * *}$ \\
\hline Central & $-3.937(6.073)$ & $0.114(0.063)^{*}$ & $0.098(0.062)$ \\
\hline Major city & $0.892(6.728)$ & $-0.057(0.089)$ & $-0.059(0.088)$ \\
\hline $\begin{array}{l}\text { Wealth in } 2012 \text { (in } \\
10,000 \text { euros) }\end{array}$ & $-0.258(0.090)^{* * *}$ & & \\
\hline $\begin{array}{l}\text { Wealth in } 2014 \text { at } 2012 \text { prices } \\
\text { (in } 10,000 \text { euros) }\end{array}$ & & $0.007(0.005)$ & $0.007(0.005)$ \\
\hline Constant & $213.369(203.819)$ & $-1.340(1.325)$ & $-1.560(1.326)$ \\
\hline$R^{2}$ & 0.05 & 0.27 & 0.27 \\
\hline$N$ & 1041 & 2328 & 2328 \\
\hline
\end{tabular}

$* p<0.1 ; * * p<0.05 ; * * * p<0.01$

precautionary purposes is one explanation for why the retired elderly in Italy dissave less than expected.

Looking next at the impact of saving for old age and saving for unexpected contingencies, both motives for saving have a positive and statistically significant 
impact on the amount of saving of the retired elderly in Italy, which provides stronger corroboration that saving for precautionary purposes may be an important explanation for why the retired elderly in Italy dissave less than expected.

Turning finally to the impact of the control variables and looking first at their impact on the wealth accumulation rate, male respondents seem to have a significantly higher wealth accumulation rate, and wealth seems to have a negative and statistically significant impact on the wealth accumulation rate. As for the impact of the control variables on the amount of saving, married respondents and respondents living in the North seem to have significantly higher amounts of saving while primary school graduates and renter households seem to have significantly lower amounts of saving.

\subsection{Summary of estimation results}

To summarize the findings of our analysis of the wealth accumulation and saving behavior of the retired elderly in Italy, our estimation results for the two waves are broadly consistent with one another and suggest that bequest motives and (to a lesser extent) saving for precautionary purposes are both important as explanations of the lower than expected wealth decumulation rates and dissaving of the retired elderly in Italy.

\section{Conclusion}

In this paper, we analyzed the wealth accumulation and saving behavior of the retired elderly in Italy using micro data from the "Survey of Italian Households' Income and Wealth," a panel survey of households conducted every two years by the Bank of Italy. We were particularly interested in shedding light on whether or not the "Wealth Decumulation Puzzle" (the tendency of the retired elderly to decumulate their wealth more slowly than expected) applies in the case of Italy, and if so, why.

To summarize our main findings, we found that, on average, the retired elderly in Italy are decumulating their wealth (dissaving) but that their wealth decumulation rates are much slower than expected. Moreover, we also found that more than $40 \%$ of the retired elderly in Italy are continuing to accumulate wealth and that more than $80 \%$ are doing positive amounts of saving. Thus, the Wealth Decumulation Puzzle (the tendency of the retired elderly to decumulate their wealth more slowly than expected) appears to apply in the case of Italy, as it does in most other countries, before as well as after the Global Financial Crisis. Moreover, our regression analysis of the determinants of the wealth accumulation and saving behavior of the retired elderly in Italy suggested that respondents with bequest motives and those saving for precautionary purposes show higher wealth accumulation rates and higher amounts of saving than other respondents, which implies that the lower than expected wealth decumulation rates and dissaving of the retired elderly in Italy is due largely to intergenerational transfers (bequests and inter vivos transfers) and saving for precautionary purposes, especially the former.

Turning next to directions for further research, the most important direction for further research is to estimate a full structural model. Another direction for further 
research is to do similar analyses for other countries and to assess whether institutional, legal, and cultural factors influence the wealth accumulation and saving behavior of the retired elderly. A comparison between Italy and Japan suggests that the wealth accumulation and saving behavior of the retired elderly in the two countries is broadly consistent but that the impact of bequest motives is relatively more important in Italy whereas the impact of saving for precautionary saving is relatively more important in Japan (see Niimi and Horioka 2019).

We turn finally to the implications of our findings. First, our findings show that the wealth accumulation and saving behavior of the retired elderly in Italy is consistent with the life-cycle model once we take account of bequest motives and saving for precautionary purposes. Second, our finding that the retired elderly in Italy are decumulating their wealth (dissaving) relatively slowly implies that Italy's household saving rate will not decline precipitously as her population ages (see Weil 1994). Third, our finding that the retired elderly in Italy are decumulating their wealth so slowly due largely to bequest motives and saving for precautionary purposes implies that we can stimulate their consumption by (1) raising inheritance taxes, thereby weakening their incentive to leave bequests, and/or (2) by expanding social safety nets, thereby alleviating their need to save for precautionary purposes.

Acknowledgements We are grateful to Ali Akkemik, Marianna Brunetti, Elena Capatina, Javier Gardeazabal, Thesia Garner, Shoshana Grossbard, Tatsuo Hatta, Takashi Kurihara, Anne Laferrere, Ran Sun Lyng, Eric D. Ramstetter, Paolo M. Silva, Timothy Smeeding, Xiaonan Sun, Tien Manh $\mathrm{Vu}$, Midori Wakabayashi, Junmin Wan, Takashi Yamashita, other participants of the Osaka University Conference on Household Economics, the Staff Seminar of the Asian Growth Research Institute, the Annual Meeting of the Society of Economics of the Household (SEHO), the Econometric Society Australasian Meeting (ESAM), the General Conference of the International Association for Research in Income and Wealth (IARIW), and the International Workshop on the Socioeconomics of Ageing (IWSEA), three anonymous referees, and especially Yoko Niimi for their valuable comments. This work was supported by JSPS (Japan Society for the Promotion of Science) KAKENHI Grant Numbers $15 \mathrm{H} 01950$ and $18 \mathrm{H} 00870$, a project grant from the Asian Growth Research Institute, a grant from the Ministry of Education, Culture, Sports, and Science and Technology (MEXT) Joint Usage/Research Center at the Institute of Social and Economic Research, Osaka University, and grant n. RP116154D0309987 from Sapienza, University of Rome.

\section{Compliance with ethical standards}

Conflict of interest The authors declare that they have no conflict of interest.

Publisher's note Springer Nature remains neutral with regard to jurisdictional claims in published maps and institutional affiliations.

Open Access This article is licensed under a Creative Commons Attribution 4.0 International License, which permits use, sharing, adaptation, distribution and reproduction in any medium or format, as long as you give appropriate credit to the original author(s) and the source, provide a link to the Creative Commons license, and indicate if changes were made. The images or other third party material in this article are included in the article's Creative Commons license, unless indicated otherwise in a credit line to the material. If material is not included in the article's Creative Commons license and your intended use is not permitted by statutory regulation or exceeds the permitted use, you will need to obtain permission directly from the copyright holder. To view a copy of this license, visit http://creativecommons.org/licenses/by/4.0/. 


\section{References}

Alessie, R., Lusardi, A., \& Kapteyn, A. (1995). Saving and wealth holdings of the elderly. Ricerche Economiche, 49(3), 293-314.

Alessie, R., Lusardi, A., \& Kapteyn, A. (1999). Saving after retirement: evidence from three different surveys. Labour Economics, 6(2), 277-310.

Altonji, J. G., \& Villanueva, E. (2007). The marginal propensity to spend on adult children. BE Journal of Economic Analysis and Policy, 7(1), 1-52.

Ameriks, J., Briggs, J. S., Caplin, A., Shapiro, M. D., \& Tonetti, C. (2020). Long-term care utility and late in life saving. Journal of Political Economy, 126(6).

Arrondel, L., \& Masson, A. (2006). Altruism, exchange or indirect reciprocity: what do the data on family transfers show?. In S. C. Kolm, J. Y. Mercier (Eds), Handbook of the economics of giving, altruism and reciprocity (vol. 2. pp. 971-1053). Amsterdam: Elsevier B.V.

Bernheim, B. D. (1987). Dissaving after retirement: testing the pure life cycle hypothesis. In Z. Bodie, J. B. Shoven \& D. A. Wise Eds, Issues in pension economics (pp. 237-274). Chicago, IL: University of Chicago Press.

Börsch-Supan, A. (1992). Saving and consumption patterns of the elderly: the German case. Journal of Population Economics, 5(4), 289-303.

Brown, M. (2006). Informal care and the division of end-of-life transfers. Journal of Human Resources, 41 (1), 191-219.

Brugiavini, A., \& Padula, M. (2001). Too much for retirement: saving in Italy. Research in Economics, 55 (1), 39-60.

Cannari, L., \& D'Alessio, G. (2008). Intergenerational transfers in Italy. In B. d'Italia (Ed.), Household wealth in Italy (pp. 255-286). Rome: Banca d'Italia.

De Nardi, M., French, E., \& Jones, J. B. (2010). Why do the elderly save? The role of medical expenses. Journal of Political Economy, 118(1), 39-75.

De Nardi, M., French, E., \& Jones, J. B. (2016). Savings after retirement: a survey. Annual Review of Economics, 8(1), 177-204.

Dobrescu, L. I. (2015). To love or to pay: savings and health care in older age. Journal of Human Resources, 50(1), 254-299.

Dynan, K. E., Skinner, J., \& Zeldes, S. P. (2002). The importance of bequests and life-cycle saving in capital accumulation: a new answer. American Economic Review: Papers \& Proceedings, 92(2), 274-278.

French, E., De Nardi, M., Jones, J. B., Baker, O., \& Doctor, P. (2006). Right before the end: asset decumulation at the end of life. Economic Perspectives, 30(3), 2-13.

Guiso, L., \& Jappelli, T. (2002). Private transfers, borrowing constraints and the timing of homeownership. Journal of Money, Credit and Banking, 34(2), 315-339.

Guiso, L., Jappelli, T., \& Padula, M. (2009). Pension risk, retirement saving and insurance. CSEF Working Papers 223. Italy: Centre for Studies in Economics and Finance, University of Naples.

Horioka, C. Y. (2010). The dis(saving) behavior of the aged in Japan. Japan and the World Economy, 22 (3), 151-158.

Horioka, C. Y. (2014). Are Americans and Indians more altruistic than the Japanese and Chinese? Evidence from a new international survey of bequest plans. Review of Economics of the Household, 12(3), 411-437.

Horioka, C. Y., Fujisaki, H., Watanabe, W., \& Kouno, T. (2000). Are Americans more altruistic than the Japanese? A U.S.-Japan comparison of saving and bequest motives. International Economic Journal, 14(1), 1-31.

Horioka, C. Y., Kasuga, N., Yamazaki, K., \& Wanatabe, W. (1996). Do the aged dissave in Japan? Evidence from micro data. Journal of the Japanese and International Economies, 10(3), 295-311.

Horioka, C. Y., \& Niimi, Y. (2017). Nihon no Koureisha Setai no Chochiku Koudou ni kansuru Jisshobunseki (An empirical analysis of the saving behavior of elderly households in Japan). Keizai Bunseki (Economic Analysis) (Economic and Social Research Institute, Cabinet Office, Government of Japan, ed.), 196, 29-47 (in Japanese).

Horioka, C. Y., \& Watanabe, W. (1997). Why do people save? A micro-analysis of motives for household saving in Japan. Economic Journal, 107(442), 537-552.

Horioka, C. Y., Yamashita, K., Nishikawa, M., \& Iwamoto, S. (2002). Nihonjin no Isan Douki no Juuyoudo, Seishitsu, Eikyou ni tsuite (On the importance, nature, and impact of the bequest motives of the Japanese). Yuusei Kenkyuusho Geppou, 163, 4-31 (in Japanese).

Hurd, M. D. (1987). Savings of the elderly and desired bequests. American Economic Review, 77(3), 298-312. 
Hurd, M. D. (1989). Mortality risk and bequests. Econometrica, 57(4), 779-813.

Hurd, M. D. (1990). Research on the elderly: economic status, retirement, and consumption and saving. Journal of Economic Literature, 28(2), 565-637.

Jappelli, T., Marino, I., \& Padula, M. (2014). Households' saving and debt in Italy. Politica Economica, (2-3), 175-202.

Jappelli, T., \& Modigliani, F. (2003). The age-saving profile and life-cycle hypothesis. CSEF Working Paper No. 9. Naples: Centre for Studies in Economics and Finance, Department of Economics, University of Naples.

Jappelli, T., \& Pagano, M. (1997). The determinants of saving: lessons from Italy. Working Paper R-313. Washington, DC: Inter-American Development Bank.

Jappelli, T., \& Pistaferri, L. (2005). The dynamics of household wealth accumulation in Italy. Fiscal Studies, 21(2), 269-295.

Jappelli, T., Pistaferri, L., \& Padula, M. (2008). A direct test of the buffer-stock model of saving. Journal of the European Economic Association, 6(6), 1186-1210.

Kopczuk, W., \& Lupton, J. P. (2007). To leave or not to leave: the distribution of bequest motives. Review of Economic Studies, 74(1), 207-235.

Laferrere, A., \& Wolff, F.-C. (2006). Microeconomic models of family transfers. In S. C. Kolm, \& J. M. Ythier (Eds), Handbook of the economics of giving, altruism and reciprocity. (vol. 2. pp. 889-969). Amsterdam: Elsevier B.V.

Laitner, J., \& Ohlsson, H. (2001). Bequest motives: a comparison of Sweden and the United States. Journal of Public Economics, 79(1), 205-236.

Lockwood, L. M. (2018). Incidental bequests and the choice to self-insure late-life risks. American Economic Review, 108(9), 2513-2550.

Miniaci, R., \& Weber, G. (2003). The wealth accumulation of Italian households: evidence from Shaw. Giornale degli Economisti, 62(1), 57-91.

Mirer, T. W. (1979). The wealth-age relation among the aged. American Economic Review, 69(3), 435-43.

Modigliani, F., \& Brumberg, R. (1954). Utility analysis and the consumption function: an interpretation of cross-section data. In K. K. Kurihara (Ed.), Post-Keynesian economics. New Brunswick: Rutgers University Press.

Murata, K. (2018). Dissaving by the elderly in Japan: empirical evidence from survey data. ESRI Discussion Paper Series No. 346. Tokyo: Economic and Social Research Institute, Cabinet Office.

Niimi, Y., \& Horioka, C. Y. (2018). The impact of intergenerational transfers on wealth inequality in Japan and the United States. World Economy, 41(8), 2042-2066.

Niimi, Y., \& Horioka, C. Y. (2019). The wealth decumulation behavior of the retired elderly in Japan: the relative importance of precautionary saving and bequest motives. Journal of the Japanese and International Economies, 51, 52-63.

Nishiyama, S. (2002). Bequests, inter vivos transfers, and wealth distribution. Review of Economic Dynamics, 5(4), 892-931.

Palumbo, M. G. (1999). Uncertain medical expenses and precautionary saving near the end of the life cycle. Review of Economic Studies, 66(2), 395-421.

Poterba, J. (1994). International comparison of personal saving. Chicago, Illinois: University of Chicago Press.

Poterba, J., Venti, S., \& Wise, D. (2011). Family status transitions, latent health, and the post-retirement evolution of assets. In D. Wise (Ed.), Explorations in the economics of aging. Chicago, Illinois, USA: University of Chicago Press.

Schunk, D. (2009). What determines the saving behavior of German households? An examination of saving motives and saving decisions. Journal of Economics and Statistics (Jahrbuecher fuer Nationalokonomie und Statistik), 229(4), 467-491.

Spicer, A., Stavrunova, O., \& Thorp, T. (2016). How portfolios evolve after retirement: evidence from Australia. Economic Record, 92(297), 241-267.

Usuki, M., Kitamura, T., \& Nakajima, K. (2016). Intai Zengo no Chukounen Kakei no Chochikudoukou (The saving behavior of middle-aged and elderly households before and after retirement). Nagoya, Japan: Mimeo, Nagoya City University (in Japanese).

Weil, D. N. (1994). The saving of the elderly in micro and macro data. Quarterly Journal of Economics, $109(1), 55-81$. 